\title{
Retaining Pin Device
}

National Cancer Institute

\section{Source}

National Cancer Institute. Retaining Pin Device. NCI Thesaurus. Code C50102.

A pin designed to fasten one object into another. 